\title{
Implementasi Pendidikan Profetik Dalam Membentuk Karakter Peserta Didik di Sekolah Dasar Al-Baitul Amien Jember
}

\author{
Sinta Yulis Pratiwi \\ IAIN Jember \\ sintapratiwi708@gmail.com \\ Lailatul Usriyah \\ IAIN Jember \\ lailatulusriyah1978@gmail.com
}

\begin{abstract}
This research was conducted at Al-Baitul Amien Elementary School Jember which aims to answer the problem 1) How is the concept of prophetic education in shaping the character of students in Al-Baitul Amien Elementary School Jember? 2) How is the implementation of prophetic education in shaping the character of students in Al-Baitul Amien Jember Elementary School? 3) How is the evaluation of prophetic education in shaping the character of students at Al-Baitul Amien Elementary School Jember? The method used in this research is qualitative research methods. The approach used is a descriptive qualitative approach. The results of this study indicate: (1) The concept of prophetic education in shaping the character of students at Al-Baitul Amien Elementary School Jember, namely: the formation of a distinctive curriculum based on the historical values of the mosque, religious habituation programs, and the commemoration of Islamic holidays. (2) Implementation of prophetic education in shaping the character of students in Al-Baitul Amien Jember Elementary School, namely: Dhuha Prayers, Dhuhr and Asr Prayers in Congregation, Asmaul Husna Habits, Tahfidz Qur'an, Juz 30 Hafalan Program, Tartil Qur'an, Tilawati Qur'an (Qiro'ah), Friday charity, Islamic Studies, Team of action / affection, Learning the Koran, PAI Subjects, Learning Arabic, Student Liaison and Achievement Books, Commemoration of Islamic Holidays, Sholawat and Hadrah, Nasyid, and Da'i Little. (3) Evacuation of prophetic education in shaping the character of students at Al-Baitul Amien Jember Elementary School, namely: a connecting book for reports on the implementation of student sunnah prayers, compulsory
\end{abstract}


prayer services, student morals at home, and also letters from parents to teachers and vice versa.

Keywords: Implementation; Prophetic Education; Character

\begin{abstract}
Abstrak
Penelitian ini dilakukan di Sekolah Dasar Al-Baitul Amien Jember yang bertujuan untuk menjawab permasalahan, 1) Bagaimana konsep pendidikan profetik dalam membentuk karakter peserta didik di Sekolah Dasar AlBaitulAmien Jember? 2) Bagaimana implementasi pendidikan profetik dalam membentuk karakter peserta didik di Sekolah Dasar Al-Baitul Amien Jember? 3) Bagaimana evaluasi pendidikan profetik dalam membentuk karakter peserta didik di Sekolah Dasar Al-Baitul Amien Jember? Pendekatan yang digunakan adalah pendekatan kualitatif deskriptif dan jenis penelitian lapangan (field research). Teknik pengumpulan data menggunakan wawancara, observasi, dan dokumentasi. Dan keabsahan datanya menggunakan triangulasi sumber dan teknik. Hasil penelitian ini menunjukkan: (1) Konsep pendidikan profetik dalam membentuk karakter peserta didik di Sekolah Dasar Al-Baitul Amien Jember yaitu: Kurikulum dibuat berdasarkan nilai historis masjid, program pembiasaan keagamaan, dan peringatan hari besar Islam. (2) Implementasi pendidikan profetik dalam membentuk karakter peserta didik di Sekolah Dasar Al-Baitul Amien Jember yaitu: melalui kegiatan Sholat Dhuha, Sholat Dhuhur dan Ashar berjamaah, Pembiasaan Asmaul Husna, Tahfidz Qur'an, Program Hafalan Juz 30, Tartil Qur'an, Tilawati Qur'an (Qiro'ah), Jum'at beramal, Kajian Islami, Tim penindak/ afeksi, Pembelajaran Al-Qur'an, Mata pelajaran PAI, Pembelajaran Bahasa Arab, Buku Penghubung dan Prestasi Siswa, Peringatan Hari Besar Islam, Sholawat dan Hadrah, Nasyid, dan Da'i Cilik. (3) Evaluasi pendidikan profetik dalam membentuk karakter peserta didik di Sekolah Dasar Al-Baitul Amien Jember yaitu: buku penghubung laporan mengenai pelaksanaan ibadah sholat sunnah siswa, ibadah sholat wajib, akhlak siswa dirumah, dan juga lembar surat dari orang tua kepada guru maupun sebaliknya.
\end{abstract}

Kata Kunci: Implementasi; Pendidikan Profetik; Karakter 


\section{PENDAHULUAN}

Pendidikan merupakan hal yang paling penting bagi kehidupan manusia. Segala potensi dan bakat dapat ditumbuh kembangkan, dan diharapkan akan dapat bermanfaat bagi diri pribadi maupun kepentingan orang banyak. Selain itu pendidikan merupakan investasi sumber daya manusia jangka panjang yang mempunyai nilai penting dan strategis bagi peradaban manusia. Hampir semua negara menempatkan pendidikan sebagai suatu hal terpenting dan utama dalam membangun suatu bangsa dan negara.

Pendidikan juga merupakan upaya yang terencana dalam proses pembimbingan dan pembelajaran bagi individu agar tumbuh dan berkembang menjadi manusia yang mandiri, bertanggung jawab, kreatif, berilmu, sehat dan berakhlak (berkarakter) mulia. ${ }^{1}$ Undang-undang Nomor 20 Tahun 2003 tentang Sistem Pendidikan Nasional (Sisdiknas) menegaskan:

Pendidikan nasional berfungsi mengembangkan kemampuan dan membentuk watak serta peradaban bangsa yang bermartabat dalam rangka mencerdaskan kehidupan bangsa, bertujuan untuk berkembangnya potensi peserta didik agar menjadi manusia yang beriman dan bertakwa kepada Tuhan Yang Maha Esa, berakhlak mulia, sehat, berilmu, cakap, kreatif, mandiri, dan menjadi warga negara yang demokratis serta bertanggung jawab. ${ }^{2}$

Pendidikan di Indonesia hingga saat ini masih menyisakan banyak persoalan, baik dari segi kurikulum, manajemen, maupun para pelaku dan pengguna pendidikan. ${ }^{3}$ SDM (Sumber Daya Manusia) Indonesia masih belum mencerminkan cita-cita pendidikan yang diharapkan. Pendidikan di Indonesia lebih menekankan pada dimensi kognitif yang mencetak manusiamanusia yang cerdas, terampil dan mahir yang melahirkan manusia yang

\footnotetext{
${ }^{1}$ Marzuki, Pendidikan KarakterIslami, (Jakarta: AMZAH, 2019), 3.

${ }^{2}$ Sekertariat Negara RI 1945, Undang-undang No. 20 Tahun 2003 Tentang Sistem Pendidikan Nasional

${ }^{3}$ Marzuki, Karakter, 4.
} 
berkepribadian dan berintegritas. ${ }^{4}$ Kurangnya penekanan terhadap aspek afektif dan psikomotorik dalam sistem pendidikan menjadikan krisis identitas serta hilangnya nilai-nilai luhur yang melekat pada bangsa Indonesia, seperti kejujuran, kesantunan, kesopanan, hormat pada orang lain, religius dan kebersamaan. Hal ini menjadi keprihatinan kita semua sebagai warga negara Indonesia. ${ }^{5}$

Situasi dan kondisi karakter bangsa yang sedang memprihatinkan telah mendorong pemerintah untuk mengambil inisiatif dalam memprioritaskan pembangunan karakter bangsa. Pembangunan karakter bangsa dijadikan arus utama pembangunan nasional. ${ }^{6}$ Hal ini mengandung arti bahwa setiap upaya pembangunan harus selalu diarahkan untuk memberi dampak positif terhadap pengembangan karakter. Griek mengemukakan bahwa karakter dapat didefinisikan sebagai paduan dari pada segala tabiat manusia yang bersifat tetap, sehingga menjadi tanda yang khusus untuk membedakan orang yang satu dengan yang lain. ${ }^{7}$ Kemudian Leonardo A. Sjiamsuri dalam bukunya "Kharisma Versus Karakter" yang dikutip Damanik mengemukakan bahwa karakter merupakan siapa anda sesungguhnya. Batasan ini menunjukkan bahwa karakter sebagai identitas yang dimiliki seseorang yang bersifat menetap sehingga sesorang atau sesuatu itu berbeda dari yang lain. Dari pengertian tersebut, jelaslah sudah bahwa misi dari pendidikan itu adalah membuat manusia menjadi manusia. Artinya pendidikan itu harus mengarahkan individu agar memiliki karakter positif dengan ciri insan yang sadar diri dan sadar lingkungannya. Tentu saja dibutuhkan waktu yang lama dan intensitas internalisasi yang mendalam untuk sampai pada keadaan itu. ${ }^{8}$

\footnotetext{
${ }^{4}$ Marzuki, Pendidikan Karakter Islam, (Jakarta: AMZAH, 2019),4.

${ }^{5}$ Zubaedi, Desain Pendidikan, 326.

${ }^{6}$ Zubaedi, Desain Pendidikan Karakter, (Jakarta: Kencana, 2015), 7.

${ }^{7}$ Zubaedi, DesainPendidikan, 9.

${ }^{8}$ Akhmad Shodiq, Prophetic Character Buildin, (Jakarta :Kencana, 2018), 1.
} 
Seluruh aktivitas pendidikan semestinya bermuara kepada pendidikan karakter (character building). ${ }^{9}$ Dengan kata lain, pendidikan harus mampu mengemban misi pembentukan karakter. Sehingga para peserta didik dan para lulusan lembaga pendidikan dapat berpartisipasi dalam mengisi pembangunan bangsa dengan baik tanpa meninggalkan nilai-nilai karakter mulia. Kurikulum tahun 2013 (K-13) yang telah disosialisasikan dan telah cukup lama diimplementasikan mulai dari tahun 2013, memiliki spirit dasar penguatan pendidikan karakter bagi para peserta didik.

Pendidikan karakter di dalam pendidikan Islam disebut juga dengan pendidikan akhlak mulia. ${ }^{10}$ Jika dilihat secara historis pendidikan akhlak mulia merupakan respon terhadap adanya kemerosotan akhlak pada masyarakat. Lahirnya agama Islam di mekkah dan berkembang pesat di madinah, bahkan setelah itu diseluruh dunia, merupakan sampling yang representative tentang perlunya agama ini membentuk akhlak masyarakat. Hal itu dapat terwujud karena keberhasilan Nabi Muhammad SAW dalam menjadi Uswah (Tauladan) yang baik untuk mengimplementasikan akhlak mulia dimasyarakat pada saat itu. ${ }^{11}$ Seperti yang termaktub dalam firman Allah SWT. :

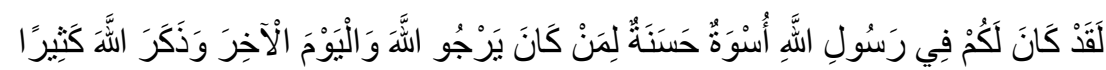

Artinya : "Sesungguhnya telah ada pada (diri) Rasulullah itu suri teladan yang baik bagimu (yaitu) bagi orang yang mengharap (rahmat) Allah dan (kedatangan) hari kiamat dan dia banyak menyebut Allah" (Q.S Al-Ahzab: 21) ${ }^{12}$

Keberhasilan Rasulullah membangkitkan umat terdahulu dari kemerosotan akhlak, merupakan bukti nyata bahwa segala pemikiran, tindakan, perkataan Rasulullah adalah suatu hal yang wajib kita pelajari dan implementasikan. Maka dari itu lahirlah pendidikan profetik. Istilah

\footnotetext{
${ }^{9}$ Marzuki, Karakter, 4.

${ }^{10}$ Akhmad Shodiq, Prophetic, 1.

${ }^{11}$ Marzuki, Pendidikan Karakter , 5.

${ }^{12}$ Tim Tashih Departemen Agama. 1995. Al Qur'an dan Tafsirnya Jilid VII. Medan: PT. Dana Bhakti Wakaf
} 
"Profetik" diambil dari kata prophetic yang berarti kenabian atau berkenaan dengan nabi. Sedangkan pendidikan profetik (prophetic education) adalah suatu metode pendidikan yang selalu mengambil inspirasi dari ajaran Nabi Muhammad SAW.

Pendidikan dalam perspektif profetik tersebut memiliki dasar tradisi akademik yang kondusif. Sebagaimana nabi SAW membangun tradisi Madinah yang memiliki daya kolektif untuk terus bergerak progresif secara kontinyu dengan pilar yang kuat. Pendidikan profetik berusaha menghadirkan nilai kenabian dalam konteks kekinian. Dengan cara pandang profetik, pendidikan Islam diharapkan mampu mencapai puncak tujuannya yaitu melahirkan manusia-manusia yang beriman kokoh dan berilmu luas (ulul albab) dan juga menjadi insan kamil. ${ }^{13}$

Wacana profetik sebenarnya telah lama berkembang baik di kalangan akademisi ataupun non akademisi. Wacana ini di latar belakangi oleh keprihatinan berbagai pihak melihat kondisi pendidikan Indonesia yang semakin lama semakin tidak memiliki identitasnya lagi, bahkan generasi muda mulai kehilangan karakter dan nilai-nilai moralnya. Selain itu, juga menyikapi output dari sistem pendidikan yang belum mampu berkontribusi bagi perbaikan negeri ini. Di tengah geliat berbagai konsep pendidikan yang muncul saat ini, pendidikan profetik dalam mengarahkan perubahannya menjadi suatu alternatif solusi bagi pendidikan di Indonesia saat ini. ${ }^{14}$

Ditengah polemik degradasi moral generasi penerus bangsa, terlebih tuntutan kurikulum dari tahun ke tahun yang membuat anak bangsa semakin kehilangan identitas dirinya. Terdapat satu sekolah dasar yang menawarkan penanaman akhlak mulia sebagai visi utama pendidikannya. Sekolah ini adalah Sekolah Dasar Al-Baitul Amien Jember. Sekolah dengan basis fullday school yang terletak di jantung kota Jember. Berbeda dengan sekolah

\footnotetext{
${ }^{13}$ Khoiron Rosyadi, Pendidikan Profetik, (Yogyakarta: Pustaka Pelajar, 2009), 301.

${ }^{14}$ Moh. Roqib, Prophetic Education: Kontektualisasi Filsafat dan Budaya Profetik dalam Pendidikan, (Purwokerto: STAIN Press, 2011), 27.
} 
dasar lainnya yang sama-sama berada dibawah naungan DIKNAS dengan pelajaran non agama yang lebih mendominasi. Sekolah ini tetap konsisten menyajikan pelajaran agama yang berimbang dengan pelajaran non agama sesuai dengan kurikulum berbasis nilai historis masjid yang dimilkinya.

Sekolah Dasar Al-Baitul Amien yang juga menerapkan Kurikulum 2013, namun menjadi berbeda saat sekolah ini tidak membuat sakralisasi pendidikan umum dan mendesakralisasi pendidikan agama. Akan tetatpi menyeimbangkan antara keduanya yakni implementasi pelajaran umum dan juga penerapan pelajaran agama yang didalamnya tekandung nilai-nilai kenabian. Tidak hanya memprioritaskan dimensi kognitif peserta didik dan mengenyampingkan dimensi afektif dan psikomotoriknya. Namun turut memaksimalkan ketiganya. Hal tersebutlah yang pada akhirnya mampu membentuk karakter positif atau akhlak mulia peserta didik sesuai dengan tujuan pendidikan profetik. Berdasarkan uraian tersebut, peneliti merasa tertarik dan perlu meneliti pembiasaan nilai- nilai kenabian atau pendidikan profetik yang ada di Sekolah Dasar Al-Baitul Amien Jember. Dengan demikian maka peneliti melakukan kajian penelitian dengan judul: "Implementasi Pendidikan Profetik dalam Membentuk Karakter Peserta Didik Di Sekolah Dasar Al-Baitul Amien Jember".

\section{METODE PENELITIAN}

Pendekatan yang digunakan dalam penelitian ini adalah pendekatan kualitatif deskriptif. Penelitian deskriptif kualitatif sebagai penelitian yang menghasilkan data deskriptif berupa kata-kata tertulis atau lisan dari orangorang dan perilaku yang dapat diamati. ${ }^{15}$ Adapun jenis penelitian yang digunakan dalam penelitian ini adalah penelitian lapangan (field research) dengan pandangan fenomonologi karena peneliti berangkat kelapangan untuk mengadakan pengamatan tentang suatu fenomena dalam suatu

\footnotetext{
${ }^{15}$ Lexy J Moleong, MetodologiPenelitianKualitatif, (Bandung: Remaja Rosdakarya, 2019), 4.
} 
keadaan alamiah. ${ }^{16}$ Dengan ini peneliti berusaha untuk mendeskripsikan data atau kejadian yang menjadi pusat perhatian yaitu implementasi pendidikan profetik dalam membentuk karakter peserta didik di Sekolah Dasar Al-Baitul Amin Jember. Adapun teknik pengumpulan data menggunakan wawancara, observasi, dan dokumentasi. Dan keabsahan datanya menggunakan triangulasi sumber dan teknik.

\section{HASIL DAN PEMBAHASAN TEMUAN}

\section{Konsep Pendidikan Profetik Dalam Membentuk Karakter Peserta} Didik di Sekolah Dasar Al-Baitul Amien Jember

Secara terminologis, makna karakter dikemukakan oleh Thomas Lickona yang mendasarkan pada beberapa definisi yang dikemukakan oleh para ahli. Ia menegaskan bahwa karakter yang baik adalah apa yang diinginkan untuk anak-anak. Lalu ia mempertanyakan, "Karakter yang baik itu terdiri dari apa saja?" Lickona kemudian menyitir pendapat Aristoteles, seorang filsuf Yunani Kuno, yang mendifinisikan karakter yang baik sebagai kehidupan dengan melakukan tindakan-tindakan yang benar sehubungan dengan diri sesorang dengan orang lain. Lickona juga menyitir pendapat Michael Novak, seorang filsuf kontemporer, yang mengemukakan bahwa karakter merupakan campuran yang harmonis dari seluruh kebaikan yang diidentifikasi oleh tradisi religius, cerita sastra, kaum bijaksana, dan kumpulan orang berakal sehat yang ada dalam sejarah. Novak menegaskan bahwa tidak ada seorang pun yang memiliki semua kebaikan, setiap orang memiliki beberapa kelemahan. ${ }^{17}$

Dari pengertian karakter diatas dapat dipahami bahwa karakter identik dengan akhlak sehingga karakter merupakan nilai-nilai perilaku manusia yang universal yang meliputi seluruh aktivitas manusia baik dalam rangka berhubungan dengan Tuhan, diri sendiri, sesama manusia, maupun

\footnotetext{
${ }^{16}$ Musfiqon, Panduan Lengkap Metodologi Penelitian Pendidikan, (Jakarta: Prestasi Public Publiser, 2012), 56.

${ }^{17}$ Marzuki, Karakter, 20.
} 
lingkungan yang terwujud dalam pikiran, sikap, perasaan, perkataan, dan perbuatannya berdasarkan norma-norma agama, hukum, tata krama, budaya, dan adat istiadat. Ahmad Amin mengemukakan bahwa, kehendak (niat) merupakan awal terjadinya akhlak (karakter) pada diri seseorang jika kehendak itu diwujudkan dalam bentuk pembiasaan sikap dan perilaku. ${ }^{18}$

Penjelasan diatas relevan dengan pembiasaan dan program-program di Sekolah Dasar Al-Baitul Amien dalam rangka pembentukan karakter. Pembiasaan tersebut meliputi sholat dhuha, jum'at beramal, dan pembentukan tim afeksi. Seperti yang telah dikemukakan oleh Lickona dengan menyitir pendapat Michael Novak, bahwa karakter merupakan campuran yang harmonis dari seluruh kebaikan yang diidentifikasi salah satunya oleh tradisi religius. Sama halnya dengan Lickona, Marzuki juga berpendapat bahwa karakter merupakan nilai-nilai perilaku manusia yang universal. Dalam hal ini meliputi seluruh aktivitas manusia baik dalam rangka berhubungan dengan Tuhan, diri sendiri, sesama manusia, maupun lingkungan yang terwujud dalam pikiran, sikap, perasaan, perkataan, dan perbuatannya berdasarkan norma-norma agama, hukum, dan lainnya.

Aktivitas yang dimaksud oleh Marzuki diatas terkait aktivitas manusia dalam rangka berhubungan dengan Tuhan, tentunya sudah terealisasi di Sekolah Dasar Al-Baitul Amien. Implementasi tersebut berupa sholat berjamaah baik sholat wajib maupun sunnah, pembacaan ayat suci AlQur'an, dan kegiatan keagamaan lainnya. Tidak hanya itu, terdapat wujud implementasi terkait aktivitas yang berhubungan dengan manusia yakni kegiatan jum'at beramal. Hal tersebut dilaksanakan tentunya dalam rangka pembentukan karakter peserta didik.

Pemaparan diatas juga diperkuat dengan teori karakter islami yang dikemukakan oleh Marzuki yakni karakter Islami adalah suatu tindakan atau perbuatan, perangai, tingkah laku dan tabiat yang berasaskan pada nilai-nilai

\footnotetext{
${ }^{18}$ Marzuki, Karakter, 21.
} 
Islam, sehingga pendidikan karakter Islami merupakan bentuk pendidikan dengan menanamkan sifat-sifat keislaman sehingga dapat membentuk tindakan atau perbuatan yang sesuai dengan aturan Islam. ${ }^{19}$

Selain pemaparan diatas, Marzuki juga menyebutkan beberapa nilainilai karakter. Nilai karakter berikut tentunya relevan dengan wujud implementasi yang berjalan dan telah terlaksana di Sekolah Dasar Al-Baitul Amien. Nilai-nilai karakter yang dimaksud yakni sebagai berikut:

a. Karakter yang bersumber dari olah hati, antara lain: beriman dan bertaqwa, jujur, amanah, adil, tertib, taat aturan, bertanggung jawab, berempati, berani mengambil resiko dan pantang menyerah.

b. Karakter yang bersumber dari olah pikir, antara lain: cerdas, kritis, kreatif, inovatif, ingin tahu, produktif, berorientasi kepada iptek, dan reflektif.

c. Karakter yang bersumber dari olah raga/ kinestetika, antara lain: bersih, sehat, sportif, tangguh, andal, berdaya tahan, bersahabat, kooperatif, determinative, kompetitif, ceria, dan gigih.

d. Karakter yang bersumber dari olah rasa dan karsa, antara lain: kemanusiaan, saling menghargai, gotong royong, kebersamaan, ramah, hormat, toleran, nasionalis, peduli, kosmopolit (mendunia), mengutamakan kepentingan umum, dinamis, kerja keras, beretos kerja. $^{20}$

Berdasarkan teori yang telah dipaparkan diatas, tentunya sangat relevan dengan konsep pendidikan profetik yang terlaksana di Sekolah Dasar Al-Baitul Amien. Contohnya pada karakter yang bersumber dari olah hati, karakter tersebut sudah tertanam dengan pelaksanaan sholat berjamaah, pembacaan asmaul husna, menghafal Al-Qur'an, dan kegiatan keagamaan lainnya yang mampu meningkatkan iman dan taqwa peserta didik. Demi

\footnotetext{
${ }^{19}$ Marzuki, Karakter, 24.

${ }^{20}$ Marzuki, Pendidikan Karakter Islam, (Jakarta :Amzah, 2019), 43.
} 
mewujudkan terbentuknya karakter yang bersumber dari olah hati ini juga akhirnya diadakan tim Aveksi untuk membiasakan ketertiban peserta didik.

Sedangkan untuk mewujudkan karakter yang bersumber dari olah pikir, dilaksanakanlah kegiatan pembelajaran PAI, pembelajaran Al-Qur'an, pembelajaran Bahasa Arab, agar siswa menjadi lebih cerdas dan terasah intelektualnya. Untuk membentuk karakter olah pikir kreatif dan inovatif maka dilaksanakan ekstrakurikuler prakarya dan kesenian islami.

Karakter yang bersumber dari olah raga/ kinestetik juga terbentuk melalui pembelajaran PJOK dan juga perlombaan yang dilaksanakan didalam sekolah ataupun luar sekolah. Hal tersebut bertujuan untuk memupuk karakter sehat dan kompetitif kepada peserta didik.

Karakter olah rasa juga terlaksana di sekolah ini, yakni dalam bentuk pembiasaan jumat beramal, perlombaan, dan upacara bendera. Hal tersebut diharapkan mampu membentuk karakter peduli, kerjasama, dan juga nasionalis.

Pembentukan karakter tentunya tidak dapat berjalan begitu saja tanpa adanya perantara untuk mewujudkan terbentuknya karakter islami. Dalam penelitian yang dilakukan di Sekolah Dasar Al-Baitul Amien ini, pembentukan karakter disertai dengan pelaksanaan pendidikan profetik yang telah terlaksana sejak lama di sekolah yang berada di pusat kota Jember ini.

Mohammad Roqib mendefinisikan pendidikan profetik sebagai proses transfer pengetahuan (knowledge) dan nilai (values) yang bertujuan untuk mendekatkan diri kepada Tuhan dan alam sekaligus memahaminya untuk membangun komunitas sosial yang ideal (khoirul ummah). Pendidikan profetik peserta didiknya dipersiapkan sebagai individu sekaligus komunitas. Untuk itu, standar keberhasilan pendidikan profetik diukur berdasarkan capaian yang menginternal dalam individu dan yang teraktualisasi secara sosial.

Strategi pendidikan profetik sebagaimana Nabi, dimulai keteladanan diri dan bangunan keluarga ideal (maslahah). Pendidik atau guru meliputi 
semua unsur dan pribadi yang terlibat dalam interaksi baik dalam keluarga maupun masyarakat. Kompetensi pendidik atau guru dalam pendidikan profetik meliputi empat hal yaitu kejujuran (sidq), tanggung jawab (amanah), komunikatif (tabligh), dan cerdas (fatanah). ${ }^{21}$

Proses transfer pengetahuan (knowledge) dan nilai (values) telah berjalan cukup efektif di Sekolah Dasar Al-Baitul Amien. Transfer of knowledge telah terlaksana melalui pelaksanaan pembelajaran PAI, pembelajaran Al-Qur'an, melalui kajian jum'at serta tausiyah singkat yang diberikan oleh para wali kelas kepada siswa-siswinya setiap pagi. Sedangkan untuk transfer of values, dewan guru memupuk pembiasaan yang bertujuan untuk mendekatkan diri pada Tuhan. Seperti pembiasaan sholat berjamah, Jum'at beramal, pembentukan tim afeksi, pembacaan Asmaul Husna, dan suri tauladan yang baik oleh dewan guru sebagai role mode bagi peserta didik.

Menjadikan Rasulullah SAW sebagai suri tauladan, membuat dewan guru senantiasa menerapkan 4 sifat Rasulullah dalam kegiatan keseharian di sekolah. Sifat-sifat Nabi yang meliputi empat hal yaitu kejujuran (sidq), tanggung jawab (amanah), komunikatif (tabligh), dan cerdas (fatanah) menjadi kompetensi pendidik di Sekolah Dasar Al-Baitul Amien.

Sekolah Dasar Al-Baitul Amien selalu berupaya mengantarkan siswasiswinya agar senantiasa memperbaiki hubungannya dengan Tuhan. Usaha tersebut diimplementasikan dalam wujud program dan pembiasaan yang terlaksana di Sekolah Dasar Al-Baitul Amien. Hal tersebut tentunya relevan dengan salah satu nilai profetik yakni transendensi. Menurut Muhammad Roqib dalam filsafat pendidikan profetik, transendensi merupakan proses transfer knowledge and values untuk pengesaan terhadap Allah yang dilakukan secara kontinu dan dinamis. Hal tersebut disertai pemahaman bahwa dalam diri ada kelebihan dan kelemahan yang menunjukkan adanya

\footnotetext{
${ }^{21}$ Roqib, Prophetic, 88.
} 
campur tangan Tuhan. ${ }^{22}$ Pemahaman terhadap kelebihan dan kelemahan ini terus berdialog dengan Tuhan yang transenden dan alam yang secara internal berwujud self correction atau muhasabah an-nafs. Dan hal tersebut secara eksternal akan berwujud amar ma'ruf (humanisasi) dan nahi munkar (liberasi).

\section{Implementasi Pendidikan Profetik Dalam Membentuk Karakter} Peserta Didik di Sekolah Dasar Al-Baitul Amien Jember

Implementasi pendidikan profetik merupakan aktualisasi dari konsep yang telah dirancang. Semua yang terlaksana dari implementasi pendidikan profetik ini tidak boleh keluar dari rel konsep yang telah dirumuskan sebelumnya. Konsep dan implementasi pendidikan profetik memang tidak jauh berbeda. Justru saling berkaitan antara satu dengan yang lainnya. Konsep pun ditetapkan berdasarkan kemampuan dan kesanggupan seluruh elemen Sekolah Dasar Al-Baitul Amien dalam aktualisasinya.

Pembiasaan yang terbangun dengan kokoh bahkan di luar kesadaran akan menggulirkan semangat keilmuan yang tinggi seperti gemar membaca, menulis, diskusi, dan membangun proyek keilmuan yang mungkin belum pernah terlintas dalam rencana mereka. Menurut Muhammad Roqib, diantara implementasi budaya profetik tersebut dapat dijelaskan sebagai berikut:

a. Membangun Tradisi dan Miliu yang Positif dan Sehat

Berdasarkan teori implementasi budaya profetik yang telah di paparkan di bab sebelumnya, tentunya relevan dengan program dan pembiasaan yang dilaksanakan di Sekolah Dasar Al-Baitul Amien. Seperti dalam membangun tradisi dan miliu yang positif juga sehat misalnya. Sekolah ini memiliki banyak program dan kegiatan yang merupakan tradisi positif, dan dilakukan secara istiqamah (kontinyu). Contohnya pelaksanaan sholat dhuha, sholat berjamaah ashar dan

\footnotetext{
${ }^{22}$ Roqib.Prophetic, 87.
} 
dhuhur, pelaksanaan program tahfidz, jum'at beramal dan masih banyak yang lainnya. Hal tersebut tentunya dapat dijadikan dasar untuk mengembangkan pilar pendidikan profetik; berdimensi transendensi kuat, humanisasi yang jelas, dan liberasi yang nyata.

b. Pemberdayaan dan Peningkatan SDM

Setiap individu membangun dan membuat impian tentang menyebar, membela, dan memberdayakan hidup agar mereka mempunyai hidup dan mempunyai kemampuan untuk memberdayakan potensinya. Ada juga reorientasi dengan cara mendahulukan kaum miskin melalui pemberdayaan rakyat dengan perspektif keadilan gender dan pemeliharaan lingkungan hidup.

Berbeda halnya dengan membangun tradisi dan miliu yang positif. Program ekstrakurikuler dan pembelajaran di kelas menjadi salah satu upaya yang dilakukan Sekolah Dasar Al-Baitul Amien dalam pemberdayaan dan peningkatan SDM (Sumber Daya Manusia). Program ekstrakurikuler dirasa cukup efektif dalam peningkatan SDM. Karena program tersebut mampu meningkatkan skill dan menumbuhkan potensi siswa.

c. Pemberantasan Kemiskinan dan Kebodohan

Pemberantasan kemiskinan dan kebodohan juga dilaksanakan di Sekolah Dasar Al-Baitul Amien. Salah satu wujud dari upaya pelaksanaan pemberantasan kebodohan tentunya melalui pembelajaran didalam kelas, dan pengenalan siswa dengan tekhnologi yang semakin canggih dan berkembang. Dengan bekal ilmu dan pemahaman teknologi yang dimiliki siswa/siswi Sekolah Dasar Al-Baitul Amien, tentunya dimasa mendatang akan mengurangi angka kemiskinan di Kota Jember.

d. Peneguhan keagamaan Inklusif

Peneguhan keagamaan inklusif juga dilaksanakan dengan mempertahankan tradisi lama yang baik dan mengambil tradisi baru yang lebih baik. Seperti halnya dalam pelaksanaan sholat berjamaah yang 
merupakan program atau tradisi lama yang berjalan di Sekolah Dasar AlBaitul Amien. Program atau tradisi baru yang diambil di sekolah ini ialah pelaksanaan program tahfidz. Juga dalam aspek peneguhan keagamaan inklusif ini ada beberapa inovasi-inovasi baru yang dilakukan dengan harapan lebih baik kedepannya.

e. Musik Edukatif

Bebeda dari program yang telah dipaparkan diatas, program musik edukatif yang bersifat kesenian juga terlaksana di Sekolah Dasar AlBaitul Amien Jember. Program musik edukatif ini terwujud dalam kegiatan ekstrakurikuler nasyid dan hadrah. Musik tersebut selain memberikan ketenangan batin dan juga meningkatkan intelegensi siswa, juga mampu mendekatkan siswa dengan Rabb dan Rasul yang dicintainya.

Harapan besar dewan guru di Sekolah Dasar Al-Baitul Amien terhadap pendidikan profetik yang telah berjalan, ialah terbentuknya karakter islami peserta didik. Fondasi yang dibangun dengan kokoh melalui pendidikan profetik, diharapkan mampu membentuk karakter islami peserta didik.

Hal tersebut selaras dengan teori yang dikemukakan oleh Marzuki terkait karakter islami. Menurutnya, karakter identik dengan akhlak. Dalam perspektif Islam, karakter atau akhlak mulia merupakan buah yang dihasilkan dari proses penerapan syariah (ibadah dan muamalah) yang dilandasi oleh fondasi akidah yang kokoh. Ibarat bangunan, karakter atau akhlak merupakan kesempurnaan dari bangunan tersebut setelah fondasi dan bangunannya kuat. Jadi, tidak mungkin karakter mulia akan terwujud pada diri sesorang jika ia tidak memiliki akidah dan syariah yang benar. Seorang muslim yang memiliki akidah atau iman yang benar, pasti akan mewujudkannya pada sikap dan perilaku seharihari yang didasari oleh imannya. 
Selain pemaparan diatas, Marzuki juga menyebutkan beberapa nilainilai karakter. Nilai karakter berikut tentunya relevan dengan wujud implementasi yang berjalan dan telah terlaksana di Sekolah Dasar Al-Baitul Amien. Nilai-nilai karakter yang dimaksud yakni sebagai berikut:

1) Karakter yang bersumber dari olah hati, antara lain: beriman dan bertaqwa, jujur, amanah, adil, tertib, taat aturan, bertanggung jawab, dan berempati.

2) Karakter yang bersumber dari olah pikir, antara lain: cerdas, kritis, kreatif, inovatif, dan memiliki rasa ingin tahu.

3) Karakter yang bersumber dari olah raga/ kinestetika, antara lain: bersih, sehat, sportif, kooperatif, kompetitif, dan ceria.

4) Karakter yang bersumber dari olah rasa dan karsa, antara lain: kemanusiaan, saling menghargai, gotong royong, kebersamaan, ramah, hormat, toleran, nasionalis, dan peduli. ${ }^{23}$

Berdasarkan teori yang telah dipaparkan diatas, tentunya sangat relevan dengan konsep pendidikan profetik yang terlaksana di Sekolah Dasar Al-Baitul Amien. Contohnya pada karakter yang bersumber dari olah hati, karakter tersebut sudah tertanam dengan pelaksanaan sholat berjamaah, pembacaan asmaul husna, menghafal Al-Qur'an, dan kegiatan keagamaan lainnya yang mampu meningkatkan iman dan taqwa peserta didik. Demi mewujudkan terbentuknya karakter yang bersumber dari olah hati ini juga akhirnya diadakan tim aveksi untuk membiasakan ketertiban peserta didik.

Sedangkan untuk mewujudkan karakter yang bersumber dari olah pikir, dilaksanakanlah kegiatan pembelajaran PAI, pembelajaran BTQ, pembelajaran Bahasa Arab, agar siswa menjadi lebih cerdas dan kritis. Untuk membentuk karakter olah pikir kreatif dan inovatif maka dilaksanakan ekstrakurikuler prakarya dan kesenian islami.

\footnotetext{
${ }^{23}$ Marzuki, Pendidikan Karakter Islam, (Jakarta: Amzah, 2019), 43.
} 
Karakter yang bersumber dari olah raga/kinestetik juga terbentuk melalui pembelajaran PJOK dan juga perlombaan yang dilaksanakan didalam sekolah ataupun luar sekolah. Hal tersebut bertujuan untuk memupuk karakter sehat dan kompetitif kepada peserta didik.

Karakter olah rasa juga terlaksana di sekolah ini, yakni dalam bentuk pembiasaan jumat beramal, perlombaan, dan upacara bendera. Hal tersebut diharapkan mampu membentuk karakter peduli, kerjasama, dan juga nasionalis.

\section{Evaluasi Pendidikan Profetik Dalam Membentuk Karakter Peserta Didik di Sekolah Dasar Al-Baitul Amien Jember}

Evaluasi yang dilaksanakan di Sekolah Dasar Al-Baitul Amien bertujuan untuk mengetahui tentang keberhasilan dan kesuksesan pelakasanaan implementasi pendidikan profetik. Dalam upaya pembentukan karakter peserta didik di Sekolah Dasar Al-Baitul Amien, perlu diketahui pembentukan karakter islami pada peserta didik tersebut tentunya akan berguna untuk menentukan langkah apa yang tepat dilaksanakan untuk melancarkan proses selanjutnya yang lebih baik.

Hasil temuan tersebut relevan dengan teori yang di jelaskan oleh Syamsul Yusuf, yang mengatakan bahwa salah satu kelebihan manusia sebagai makhluk Allah SWT adalah dianugerahi fitrah (perasaan dan kemampuan) untuk mengenal Allah dan melakukan ajarannya. Dalam kata lain manusia dikaruniai insting religius (naluri beragama). Karena memiliki fitrah ini, kemudian manusia dijuluki sebagai "homo devinans" dan "homo religious" yaitu makhluk ber-Tuhan atau beragama. Fitrah beragama ini merupakan disposisi (kemampuan dasar) yang mengandung kemungkinan atau peluang untuk berkembang. Namun, mengenai arah dan kualitas perkembangan beragama manusia sangat tergantung pada proses pendidikan yang diterimanya. Salah satu hakikat wujud manusia, bahwa manusia adalah makhluk yang berkembang karena dipengaruhi pembawaan dan lingkungan. 
Sedangkan bentuk dari hakikat wujud yang dimilikinya adalah kecenderungan untuk beragama. ${ }^{24}$

Barometer yang digunakan sebagai alat untuk mengetahui bagaimana evaluasi pendidikan profetik dapat membentuk karakter peserta didik ialah dengan buku penghubung. Sekolah Dasar Al-Baitul Amien telah lama menggunakan buku penghubung sebagai alat komunikasi antar guru dan wali murid. Selain sebagai alat komunikasi, buku penghubung juga berfungsi sebagai alat evaluasi guru untuk mengetahui perkembangan peserta didiknya.

Buku penghubung merupakan salah satu bentuk sinergitas antara guru dan wali murid di Sekolah Dasar Al-Baitul Amien Jember. Sinergitas orang tua dan guru di Sekolah Dasar Al-Baitul Amien Jember sangat terlihat dan berjalan efektif. Terbukti dengan tersedianya buku penghubung sebagai sarana komunikasi antar guru dan orang tua. ${ }^{25}$ Walaupun guru tidak 24 jam bersama siswa, namun dapat mengetahui kegiatan siswa dan apa yang tidak dilaksanakan melalui buku penghubung. Orang tua walaupun tidak bisa setiap hari bertemu langsung dengan guru, namun dapat melaporkan aktifitas/ kegiatan putra/ putrinya di rumah kepada guru melalui buku penghubung. Didalam buku penghubung tertera laporan mengenai pelaksanaan ibadah sholat sunnah siswa, ibadah sholat wajib, akhlak siswa dirumah, dan juga lembar surat dari orang tua kepada guru maupun sebaliknya. $^{26}$

Sebagaimana yang dikutip dalam buku Prophetic Education yang menyatkan bahwa, evaluasi pendidikan profetik merupakan cara atau teknik penilaian terhadap tingkah laku anak didik berdasarkan perhitungan yang bersifat komprehensif dari seluruh aspek-aspek kehidupan mental-

\footnotetext{
${ }^{24}$ Syamsul Yusuf, Psikologi Perkembangan Anak dan Remaja, (Bandung: PT. Remaja Rosdakarya, 2009), 136.

${ }^{25}$ Observasi Sekolah Dasar Al-Baitul Amien Jember 2019.

${ }^{26}$ Observasi Sekolah Dasar Al-Baitul Amien Jember 2019.
} 
psikologis dan spiritual-psikologis. Sasaran evaluasi pendidikan profetik secara garis besar meliputi empat kemampuan dasar anak didik yaitu :

a. Sikap dan pengalaman pribadinya, hubungannya dengan Tuhan;

b. Sikap dan pengalaman dirinya, hubunganya dengan masyarakat;

c. Sikap dan pengalaman kehidupannya, hubungannya dengan alam sekitar;

d. Sikap dan pandangannya terhadap dirinya sendiri selaku hamba Allah dan selaku anggota masyarakat, serta selaku Kholifah di muka bumi.

Teori diatas relevan dengan penilaian yang terdapat dalam buku penghubung Sekolah Dasar Al-Baitul Amien. Melalui buku penghubung, siswa dinilai pelaksanaan sholat dan ibadahnya; bagaimana ia mampu bersikap baik terhadap sesama dan sopan santun kepada yang lebih tua; dan apakah anak mampu melaksanakan tugas yang diberikan oleh guru sebagai pekerjaan rumah.

Berdasarkan hasil temuan peneliti dan relevansinya dengan teori yang digunakan, evaluasi yang dilaksanakan di Sekolah Dasar Al-Baitul Amien tentunya efektif untuk mengukur tingkat ketercapaian pendidikan profetik. Sebagaimana yang dikemukakan Moh. Roqib, evaluasi pendidikan profetik selain mengukur dan menilai tentang kualitas pemahaman, penguasaan, kecerdasan, dan keterampilan, juga mengukur dan menilai nilai moral dan akhlak peserta didik. Akhlak yang berdimensi tauhid, hubungan kepada Allah (hablum min Allah), hubungan terhadap sesama manusia (hablum min an-naas), dan hubungan dengan alam untuk memberikan rahmat bagi alam semesta (rahmatan lil al-alamin) sebagai pemakmur bumi (khalīfah fi al$\operatorname{ardh})$.

Karakter islami yang tertanam kuat pada anak tingkat sekolah dasar, tentunya membuat setiap aktivitas yang dilakukannya akan diliputi nilai karakter islami. Hal itulah yang diharapkan dan menjadi tujuan utama pelaksanaan pendidikan profetik di Sekolah Dasar Al-Baitul Amien. Hal tersebut seperti yang dipaparkan oleh Marzuki bahwa, karakter identik dengan akhlak sehingga karakter merupakan nilai-nilai perilaku manusia 
yang universal yang meliputi seluruh aktivitas manusia baik dalam rangka berhubungan dengan Tuhan, diri sendiri, sesama manusia, maupun lingkungan yang terwujud dalam pikiran, sikap, perasaan, perkataan, dan perbuatannya berdasarkan norma-norma agama, hukum, tata krama, budaya, dan adat istiadat.

\section{SIMPULAN}

Berdasarkan hasil penyajian dan analisis temuan penelitian, maka dapat disimpulkan sebagai berikut: (1) Konsep pendidikan profetik dalam membentuk karakter peserta didik di Sekolah Dasar Al-Baitul Amien Jember yaitu: pembentukan kurikulum khas yang dibuat berdasarkan nilai historis masjid, program pembiasaan keagamaan, dan peringatan hari besar Islam. (2) Implementasi pendidikan profetik dalam membentuk karakter peserta didik di Sekolah Dasar Al-Baitul Amien Jember yaitu: Sholat Dhuha, Sholat Dhuhur dan Ashar Berjamaah, Pembiasaan Asmaul Husna, Tahfidz Qur'an, Program Hafalan Juz 30, Tartil Qur'an, Tilawati Qur'an (Qiro'ah), Jum'at beramal, Kajian Islami, Tim penindak/ aveksi, Pembelajaran Al-Qur'an, Mata pelajaran PAI, Pembelajaran Bahasa Arab, Buku Penghubung dan Prestasi Siswa, Peringatan Hari Besar Islam, Sholawat dan Hadrah, Nasyid, dan Da'i Cilik. (3) Evakuasi pendidikan profetik dalam membentuk karakter peserta didik di Sekolah Dasar AlBaitul Amien Jember yaitu: buku penghubung laporan mengenai pelaksanaan ibadah sholat sunnah siswa, ibadah sholat wajib, akhlak siswa dirumah, dan juga lembar surat dari orang tua kepada guru maupun sebaliknya. 


\section{DAFTAR PUSTAKA}

Abdullah, M. Yatimin. Studi Akhlak dalam Perspektif Al-Qur'an. Jakarta: AMZAH, 2007.

Adi Pradana, Irfan Wahyudi. Konsep Pendidikan Profetik di Era Globalisasi dan Relevansinya Terhadap Pendidikan Agama Islam (Telaah Pemikiran Kuntowijoyo). Skripsi-UIN Sunan Kalijaga, 2016.

Adz-Dzakiey, Hamdani Bakran. Prophetic Psychology: Psikologi Kenabian, Menghidupkan Potensi dan Kepribadian Kenabian dalam Diri. Yogyakarta: Pustaka Al-Furqon, 2007.

Astuti, Puji. Nilai-Nilai Profetik dan Implikasinya Bagi Pengembangan Kurikulum Pendidikan Agama Islam (Studi Pemikiran Kuntowijoyo). Skripsi-Fakultas Tarbiyah dan Ilmu Keguruan UIN Raden Intan Lampung, 2018.

Aziz, Moh. Ali. Mengenal Tuntas Al-Qur'an. Surabaya: Imtiyaz, 2012.

Basrowi, Suwandi. Memahami Penelitian Kualitatif. Jakarta: Rineka Cipta, 2008.

Erbe, Sentanu. Quantum Ikhlas: Tekhnologi Aktivasi Kekuatan Hati, The Power of Positive Feeling. Jakarta: Gramedia, 2017.

Freire, Paulo. Pendidikan Kaum Tertindas. Jakarta: LP3ES, 1985.

Hani'ah, Zuhrotul. Implementasi Nilai-Nilai Pendidikan dalam Meningkatkan Kualitas Pembelajaran IPS Kelas VII di MTsN 1 Malang. Skripsi-UIN Maulana Malik Ibrahim Malang, 2018.

Hassan Shadily, dan John M. Ecols. Kamus Inggris Indonesia. Jakarta: Gramedia, 1996.

Ismail, Syaifullah Godi. Implementasi Pendidikan Profetik dalam Pembelajaran Pendidikan Agama Islam di SMP Negeri 4 Salatiga. Skripsi-IAIN Salatiga, 2015.

Izutsu, Toshihiko. Konsep-konsep Etika Religius dalam Qur'an. Yogyakarta: Tiara Wacana, 1993.

Khoiron, Rosyadi. Pendidikan Profetik. Yogyakarta: Pustaka Pelajar, 2009.

Kuntowijoyo. Islam Sebagai Ilmu. Yogyakarta: Tiara Wacana, 2007.

Kuntowijoyo. Muslim Tanpa Masjid. Yogyakarta: IRCiSoD, 2018.

Lestari, Elani Dwi. Nilai Pendidikan Profetik dalam Film Sang Kiai. Skripsi-IAIN Purwokerto, 2019. 
Lickona, Thomas. Character Matters: Persoalan Karakter (Bagaimana Membantu Anak Mengembangkan Penilaian yang Baik, Integritas, dan Kebajikan Penting Lainnya. Jakarta: Bumi Aksara, 2016.

Marzuki. Pendidikan Karakter Islam. Jakarta: Amzah, 2019.

Miftahulloh. Pendidikan Profetik Perspektif Moh. Roqib dan Implikasinya dalam Rekonstruksi Pendidikan Islam Integratif. Tesis-IAIN Purwokerto, 2017.

Mujib, Abdul. Kepribadian dalam Psikologi Islam. Jakarta: PT Raja Grafindo Persada, 2016.

Musfiqon. Panduan Lengkap Metodologi Penelitian Pendidikan. Jakarta: Prestasi Public Publiser, 2012.

Pusat Bahasa DEPDIKNAS. Kamus Besar Bahasa Indonesia. Jakarta: Balai Pustaka, 2008.

Robani, Ahmad. Implementasi Pendidikan Profetik dalam Membentuk Karakter Siswa di MTs Negeri 6 Sleman Yogyakarta. SkripsiUniversitas Islam Indonesia Yogyakarta, 2018.

Roqib, Moh. Prophetic Education. Purwokerto: STAIN Press, 2011.

Rosyadi, Khoiron. Pendidikan Profetik. Yogyakarta : Pustaka Pelajar, 2009.

Shihab, M Quraish. Membumikan Al-Qur'an. Bandung: Mizan, 1993.

Sodiq, Akhmad. Prophetic Character Building. Jakarta : Kencana, 2018.

Subhani. Tadarrus Akhlak: Etika Qur'ani dalam Surah Al-Hujurat. Jakarta: Citra, 2014.

Syarif, Zainuddin. Pendidikan Profetik dalam Membentuk Karakter Bangsa. Jurnal Tadris, 2014.

Tim Tashih Departemen Agama. Al Qur'an dan Tafsirnya Jilid IX. Medan: PT. Dana Bhakti Wakaf, 2009.

Trueblood, David. Philosophy of Religion; Filsafat Agama. Jakarta: Bulan Bintang, 1994.

Yusuf, Syamsul. Psikologi Perkembangan Anak dan Remaja. Bandung: PT. Remaja Rosdakarya, 2009.

Zubaedi. Desain Pendidikan Karakter. Jakarta: Kencana, 2015. 